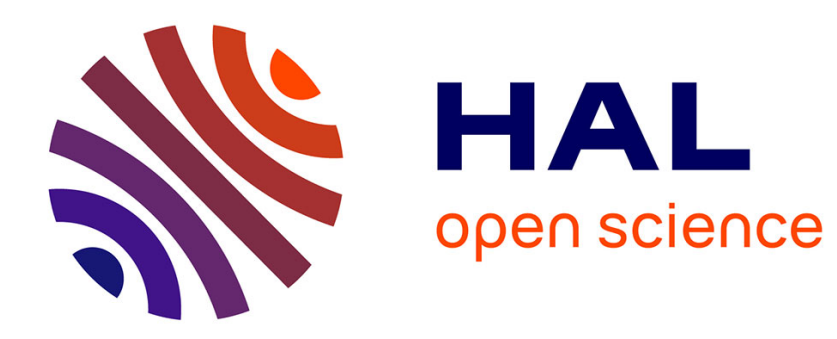

\title{
The Foundations of Justice in Jules Dupuit's Thought Philippe Poinsot
}

\section{To cite this version:}

\begin{tabular}{|l}
$\begin{array}{l}\text { Philippe Poinsot. } \\
\text { Thought. }\end{array}$ The Foundations of Justice in Jules Dupuit's \\
$\begin{array}{l}\text { (4), } \\
\text { 10.1080/09672567.2010.499472 . hal-00644523 }\end{array}$
\end{tabular}

HAL Id: hal-00644523

https://hal.science/hal-00644523

Submitted on 24 Nov 2011

HAL is a multi-disciplinary open access archive for the deposit and dissemination of scientific research documents, whether they are published or not. The documents may come from teaching and research institutions in France or abroad, or from public or private research centers.
L'archive ouverte pluridisciplinaire HAL, est destinée au dépôt et à la diffusion de documents scientifiques de niveau recherche, publiés ou non, émanant des établissements d'enseignement et de recherche français ou étrangers, des laboratoires publics ou privés. 


\title{
The Foundations of Justice in Jules Dupuit's Thought
}

\section{Philippe Poinsot ${ }^{*}$}

June 2010

\begin{abstract}
The ongoing interpretation of Dupuit's conflict with the French liberal school on the question of justice consists of a simple opposition between public utility and natural rights. This paper aims to show that Dupuit's position is far more complex: justice is based on welfare - and thus on public utility - although natural rights are not excluded from his scheme. An understanding of Dupuit's concept requires a clarification of the differences between three notions - public interest, welfare and public utility - and, by the same token, of the factors linking each notion to the others.
\end{abstract}

Key words: Jules Dupuit, justice, general interest, welfare, the School of Paris Classification J.E.L.: B19, D63, H11, H21.

\section{Introduction}

The question of justice was a much-debated issue in $19^{\text {th }}$ century France. Against the backdrop of the 1848 revolution, the development of social doctrines and, more broadly, the political context of the time (Sagot-Duvauroux, 2002a, 2002b), these debates focused on the possible foundations of property rights.

Dupuit and French liberal economists ${ }^{1}$ do not share the same position. Many members of the liberal school - such as Bastiat, Frederic Passy or Baudrillart - assert that the law must

\footnotetext{
*I wish to thank Alain Béraud, Shirine Sabéran, Gilbert Faccarello and Nathalie Sigot for their helpful comments on an earlier version of this paper. I would also like to thank all the participants at the Xle Université d'été en Histoire, Philosophie et Pensée Economiques (Paris, September 1-5, 2008), the History of Public Economics Conference (Paris, December 10-12, 2008). Finally, I would like to thank all the referees of EJHET, in particular one of them who provided me with considerable help. Philippe Poinsot, PHARE, Universite Paris 1, Philippe.Poinsot@univ-paris1.fr.
}

${ }^{1}$ The term "liberal" is used here in the French sense of the word, referring to the nineteenth century economists who believed that free market conditions were more effective than State intervention in the economy. I will adopt a restrictive definition of the French liberal school, which Michel Leter (2006) calls the School of Paris. Furthermore, in order to limit the number of authors cited from the School of Paris, I will only refer to those with whom Dupuit debated on the question of the foundation of property rights. This explains why certain important authors, such as Jean-Baptiste Say and Pellegrino Rossi, are not studied in this paper, despite the fact that they influenced both the French liberal school and Jules Dupuit. 
conform to natural rights whereas Dupuit, following the example of Turgot and Condorcet ${ }^{2}$, feels that property rights do not stem from natural law but from public utility. This position isolated him from the French liberals and led some commentators to consider him as a utilitarian. Hence, Vatin (2002, p. 106) states that, "the utilitarianism of Dupuit is without ambiguity". 3

Contrary to what is becoming the usual interpretation, I argue that Dupuit's opposition to the majority of the members of the French liberal school does not consist of a simple opposition between public utility and natural rights. As I have already mentioned, most French liberal economists believe that legislation must conform to natural rights in order to maximize the welfare of society: hence justice is based on natural rights and is therefore referred to as "natural justice" (Baudrillart, 1867, p. 15). On the contrary, Dupuit believe that natural rights may be in conflict with each other; consequently, legislation cannot be entirely founded on these rights but on another criterion that he calls "general interest" or "public interest" ${ }^{4}$ (section 2). However, natural rights are not excluded from Dupuit's scheme (section 3). The law may have to restrict natural liberty - which is a natural right - whenever this is necessary to increase the wealth and thus the welfare of the nation. The law must nevertheless protect the other natural rights - self-ownership, self-defense and the respect of contracts. We will show that both arguments arise from public interest while the former is also based on a different concept - that of public utility.

Dupuit's analytical framework is therefore based on three specific notions:

1) The goal of society - or of the social contract - is to maximize the welfare of the nation by restricting natural liberty as little as possible and protecting the other natural rights. As we will see, the welfare of the nation is measured by average life expectancy and,

\footnotetext{
${ }^{2}$ According to Turgot and Condorcet, even if the right of property is a natural right it can be regulated by public utility. See Faccarello (2006, pp. 10-12).

${ }^{3}$ Ekelund and Hébert are more cautious. They claim that "Dupuit was a utilitarian in the broad sense, and in a manner that reflected the tradition of Bentham, Pascal, Montesquieu, and Mirabeau" (1999, p. 307). SagotDuvauroux (2002a, 2002b) only refers to utilitarianism when dealing with Dupuit's position concerning property rights.

${ }^{4}$ Echoing Dupuit, I will consider the terms 'general interest' and 'public interest' to be synonymous. Dupuit's reference to general interest surely stems from his education at the Polytechnique and the Ecole des Ponts et Chaussées. The notion certainly existed in engineering concepts taught at the Polytechnique and the Ecole des Ponts et Chaussées, which constantly made reference to public interest. On this point, see Etner (1987); Grall (2004), p. 31; M osca (1998) and Smith (1990).
} 
according to Dupuit, is determined by two factors: moral responsibility and the ratio of the quantity of wealth to the population level;

2) The general or public interest consists of achieving the goal of the social contract;

3) Public utility is a quantitative notion that political economy indicates to the legislator in order to increase wealth.

These three notions are central to an understanding of Dupuit's thought and his specificity compared to his contemporaries.

\section{From natural rights to public interest}

All the authors of the French liberal school - Courcelle-Seneuil excluded (Sigot, 2010) - consider that, before entering the state of society, individuals have rights, referred to as natural rights. These rights are either a "gift" from God (Bastiat, 1848/1854-5, pp. 277-8) or from Providence and they are located in the consciousness of human beings (Sigot, 2010, pp. 12-13). Humans have an innate knowledge of these natural rights (Ibid), and as it is innate, the liberals assert that the experience and the observation of human nature prove their existence: "killing, beating, stealing or fraudulously failing to deliver what has been promised to be returned are unjust actions. Does your consciousness not cry out, even if there are no written laws? Well! This is what we call the natural right" (Baudrillart, 1867, p. 14; see also 1857, pp. 33-34). ${ }^{5}$

In the same way, Dupuit states that natural rights "are located in consciousness" (Société d'économie politique (SEP), 1862, p. 153). He proves their existence through the observation of human behavior:

"The essence of the natural right is to be the same everywhere and at any time. If I am attacked, if somebody tries to kill me, I do not need to open the [civil] code to know if I have the right to defend by myself. Wherever I am, in France, in England, in Spain, in China, I am certain not to be violating the law by repelling an aggression that I did not provoke, or even by killing an individual who wanted to kill me, if I cannot defend my life by another means, because the right of selfdefense is a natural right that every reasonable human being recognizes" (Dupuit, 1861a, p. 330).

\footnotetext{
${ }^{5}$ All translations throughout the paper are mine.
} 
In this consensus, however, one can find two important divergences between Dupuit and the French liberal school: the first concerns the range of these rights (2.1) while the second is a matter of their role with regard to justice (2.2).

\title{
2.1. The range of natural rights: opposition on the question of property rights
}

According to the French liberals, natural rights can be grouped into five types: 1) selfownership (body, faculties and labor), 2) self-defense, 3) natural liberty, 4) the respect of free contracts and conventions and 5) ownership of things.

The liberals all accept the idea of a hierarchical and logical link among these rights: the most important natural right is the self-ownership, since every other natural right stems from this. Indeed, as long as we accept that a man is the owner of his own person (item 1 above), we must accept his right to defend his body against external attacks (item 2), his freedom to enter into contracts which is a part of natural liberty (item 3) and to respect them (item 4).

As for property rights, the French liberals put forward an argument that can now be found in libertarian thought. According to (1) we know that individuals are the owners of their own faculties and their own labor; thus objects made through an individual's work are the property of that individual (item 5) (Bastiat, 1847/2002, p. 39 \& p. 468; Faucher, 1852, p. 464; Garnier, 1875, p. 97). For example, Baudrillart assumes that before human labor, land was inappropriate to humans, and he affirms that the first individual to cultivate it through his own labor thus becomes its owner.

\begin{abstract}
"Bare land! But do you know what bare land is? It is blackberry bushes and reptiles, it is pestilent swampland, it is wrestling, it is pain... It is often death that occurs after horrible deprivations and illnesses that slowly consume the epic pioneer of culture and civilization...". "In cultivating land, it is necessary to... [make] many thorough preparations which become inseparable from the land. Landed property is less of an instrument within the state of nature, which is not worth anything without some form of work, than an advanced tool... Everything that the owner adds... [to the land] by his labour and capital belongs to him..." $\left(1867\right.$, p. $34 \&$ p. 39). ${ }^{6}$
\end{abstract}

When the French liberals claim that the natural state of lands is not adapted to human life, they do not assume that the quantity of land is insufficient (Bastiat, 1847/2002, p. 41), only that the quality of land is very poor. This is an essential point in understanding their position

\footnotetext{
${ }^{6}$ See also Baudrillart (1857, pp. 34-5) and Garnier (1846, p. 179 \& p. 318).
} 
on justice in land distribution. Indeed, the latter is the result of the differences of humans in nature, since individuals are born with unequal faculties (Garnier 1873, p. $62 \&$ p. 491) ${ }^{7}$.

Dupuit opposes the French liberals with his conception of property rights, even though he accepts their idea of a hierarchy among the remaining natural rights and their logical connection: he claims that the right of property is not a natural right but a human invention. ${ }^{8}$ He rejects property rights as natural for two reasons.

First, he contests the way in which Baudrillart and the French liberal school depict the natural state of land: "human beings do not create anything...[T]here are trees and plants whose roots, stems, flowers or fruit could immediately serve as food [in the natural state of nature]. We can affirm this [point]..., because if this was not so, the animal species that we possess, humans included, would have perished..." (Dupuit, 1861a, p. 325). He considers that the link between self-ownership and the individual right of property over land is inappropriate. He even states that, from his own standpoint, the reference to natural rights and to a state of nature reinforces the socialist position. If, in the natural state, land was the property of all human beings and supplied products in abundance independent of the will and the work of these humans, the products would not therefore be the result of individual work as asserted by the French liberals. ${ }^{9}$ Thus the individual property right over land would, as the socialists claim, merely be the result of violence (Ibid, pp. 326-28 \& pp. 338-339; SEP, 1855, pp. 146-7). Moreover Dupuit adds that, even if we admitted that they were true, the arguments of the school of Paris could only legitimize primitive land owners and not the current ones (1861a, pp. 329-30).

The second argument deals with the existence of different modes of appropriation of wealth, depending on the nation and the timeframe. Consequently, individual property rights cannot be natural, since natural rights are essentially the same everywhere and at any time (Ibid, p. 330) while property rights are not.

\footnotetext{
${ }^{7}$ On this point, see Sigot (2010, p. 14).

${ }^{8}$ In his position on property rights, Dupuit cites the influence of many authors such as Pascal, M ontesquieu and M irabeau. On this point, see Ekelund and Hébert (1999, p. 307), Vatin (2002) and Sagot-Duvauroux (2002b).

${ }^{9}$ The same argument is used for intellectual property rights because of the community chest (see Dupuit, 1861b). This argument is relevant for land property and intellectual property, but not for all property rights. For instance, property rights in industrial production only arise from human labour. However, in support of Dupuit, it should be noted that his argument is linked with debates at that time in France which entirely concerned land and intellectual works.
} 
"M. Dupuit absolutely admits that there are natural rights, but he denies that the property right is one of them. The principles of natural right are more limited than we generally think: one may consider only what makes part of the human consciousness and what is recognized in all nations. Humans have made and can make many conventions about property rights without violating the natural right" (SEP, 1862, p. 153).

The existence of various means of appropriating wealth - either private or collective - leads Dupuit to distinguish between "natural rights" and "natural sentiments" ${ }^{10}$, and to consider that property rights are a natural sentiment. He specifies that:

"Natural sentiment leads to good or bad, just or unjust actions; whereas the natural right only has justice as its purpose and motive. If we say that natural sentiments, which motivate man to appropriate all things that can procure his happiness, has motivated and accelerated the establishment of property ownership in society, I will not deny this assertion; but if we say that this sentiment creates rights, we are mistaken." (Dupuit, 1861a, p. 328-329).

This distinction between natural right and natural sentiment is not easy to understand. Dupuit's position could be understood in the following way: the property right varies according to time and space. Thus, it cannot be a natural right. However, it is a natural sentiment:

i. It is a sentiment because any sentiment is changeable, depending on the culture of individuals (see for example SEP, 1855, p. 145);

ii. It is natural because, in order to satisfy their needs, individuals spontaneously appropriate things (in either an individual or collective way);

iii. Consequently, this natural sentiment does not create rights.

In order to demonstrate that the property right is not a natural right, Dupuit argues the existence of different means of appropriating wealth from one country to another. I find this argument controversial because he actually combines two different subjects: facts and rights. Even if facts do not prove a natural right, this does not mean that a right is not natural - for instance even if one does not use self-defense, it is still a natural right. ${ }^{11}$ Furthermore, this approach may even be used against the right to self-ownership. As long as different forms of slavery legislation exist, it may be concluded that self-ownership is not a natural

\footnotetext{
${ }^{10}$ The French liberals do not distinguish between natural sentiments and natural rights and use these words synonymously. See Garnier, for example (1875, p. 96).

${ }^{11}$ Nevertheless, as soon as the School of Paris uses an observation as proof of the existence of natural rights, the existence of differences in the means of appropriating wealth between countries constitutes a criticism of French liberals' conception of natural rights.
} 
right. This is a crucial issue: if self-ownership is not a natural right, there would be no natural rights at all, yet Dupuit provides no argument to justify self-ownership as a natural right. He simply states that "slavery violates the principles of moral and of natural right..." (SEP, 1863b, p. 473; see also SEP, 1862, p. 149).

For Dupuit, the suitable means of appropriating wealth is only defined according to public utility: it is this criterion that enables the legislator to judge if private appropriation is more suitable in a particular case than collective appropriation. In fact, public utility provides the basis for calculating which mode of appropriation increases the volume of production more quickly; this is the sole condition that matters. Dupuit claims that individual appropriation of land is better than collective appropriation in terms of increasing agricultural output, as it stimulates self-interest. Moreover, in increasing the intellectual satisfaction of the property owner and his sense of responsibility, this mode increases the welfare of the nation. ${ }^{12}$ Dupuit asserts that this mode of "appropriation is [...] excellent for two reasons: excellent for the landowners, because they find particular pleasures in it which encourage them to prefer this kind of appropriation over others; excellent for those who are not landowners, because this [mode of appropriation] gives them the greatest amount of product for the cheapest price." (Dupuit, 1861a, p. 347).

\subsection{Potential incompatibility among natural rights}

As mentioned above, the French liberal school believes that natural rights are the only source of justice. These rights are unquestionable; they cannot be limited by the legislator.

Dupuit criticizes this position because there might be an incompatibility among different natural rights. More precisely, there is an incompatibility between self-ownership and natural liberty. Consequently, they cannot be the only source of justice. Imagine for instance that you "need an amount of money in order to save your honor..., you go to find a rich man and you tell him: Give me this amount of money, and you will have over me all the rights that you have over your horse; in short, I will be your slave" (Dupuit, 1861b, p. 42). Natural liberty means that you are free to undertake a contract. This implies that you can

\footnotetext{
${ }^{12}$ The definition of welfare will be given in section 3.1.
} 
sell your person in any circumstances whatsoever and nobody could prevent you from doing so. However, doing this means that you will forego your right of self-ownership. This is the only example that Dupuit gives to prove the possibility of an incompatibility among natural rights.

It is interesting that Dupuit implicitly states that there is no criterion for choice in this conflict among natural rights - in this case the self-ownership and natural liberty. This is why Dupuit introduces a higher criterion: public interest. The legislator has to protect selfownership by restricting natural liberty because, as I have already stated, self-ownership is the most important natural right (cf. 2.1): "whenever public interest appears, the law mediates in order to restrict the individual [natural] right [...] The law will not ratify [a contract to sell your person]. You can sell your field, but you cannot sell your person; you have over your field rights that you do not have over yourself" (Ibid, p. 42). By extension, Dupuit refuses any compensation to slave owners (SEP, 1863b, p. 473) even though public expropriation compensations must in principle be provided by the legislator. ${ }^{13}$

However, Dupuit's criticism is not really relevant, since he uses a different conception of the boundaries of natural liberty from that of the French liberal school. They both share the idea that natural liberty means free will and the absence of any interference or constraint in terms of individuals' actions and the freedom of individuals to enter into contracts - the "negative liberty" of Isaac Berlin. However, they differ with respect to the boundaries of natural liberty. The French liberal school posits that natural liberty is limited by the rights of others (Bastiat, 1848/1854-5, p. 282; Garnier, 1864, p. 274; M olinari, 1861, p. VI-VII), while Dupuit implicitly distinguishes two kinds of liberty:

i. Natural liberty, which means that the freedom of individuals is unlimited (Dupuit, $1861 b$, p. 51) and only concerns the state of nature;

ii. The liberty of individuals in society, in other words the liberty approved by laws (see 3.2).

Consequently, the French liberals' definition of natural liberty renders the question of incompatibility moot because humans can only appropriate things, but not other humans. On the contrary, this problem may arise when liberty is defined as unlimited.

\footnotetext{
${ }^{13}$ Dupuit's position on public expropriation is explained in 3.2
} 
The introduction of the notion of public interest thus becomes necessary in order to eliminate this conflict among natural rights. I will now clarify this notion and its relation to Dupuit's conception of justice. This will lead me to explain the status of the notion of welfare in Dupuit's thought.

\section{The dual sources of ethical justice in Dupuit's thought: welfare and natural rights}

Natural rights, according to Dupuit, cannot be the only decision-making tool for the legislator. As he states, the legislator aims to achieve the objective of the social contract of increasing the welfare of the country and the protection of certain natural rights. This objective results from an agreement or a contract between all members of society. As there is a positive correlation both between welfare and wealth and between wealth and public utility, public utility is a priority decision-making tool to increase welfare. Dupuit continues by assuming that public utility is a norm for public decisions: it indicates whether or not laws are just. Another concept of justice therefore appears which is ethical rather than legal in nature (3.1). In addition to public utility, some natural rights also constitute a source of ethical justice (3.2). This dual source of ethical justice is relevant to a better understanding of Dupuit's economic views and in particular his position regarding the problem of financing public goods (3.3).

\subsection{Justice and public utility}

The objective of society is to maximize the welfare of the nation (Dupuit, 1861a, $p$. 334). In this framework, general interest is a formal notion without any substance in itself; it consists only of achieving the goal of the social contract. ${ }^{14}$ Laws are enforced in order to attain this goal. A clarification of the notion of welfare is therefore essential.

\footnotetext{
${ }^{14}$ Since general interest is an exclusively formal notion, trying to define it without any reference to the objective of society is absurd.
} 


\subsubsection{The objective of society: the welfare of the population}

The "purpose of society is the welfare of its members" (Dupuit, 1861b, p. 53). ${ }^{15}$ But what is welfare ${ }^{16}$ ? Dupuit does not provide any clear definition of this notion of welfare. ${ }^{17} \mathrm{He}$ nevertheless clearly explains its causes (economic and moral) and its consequences for the population.

Dupuit identifies two causes of welfare, one economic and the other moral. On the one hand, increasing wealth in society enhances the welfare of the population (Dupuit, 1865, p. 28). ${ }^{18}$ It seems that the wealth of a nation is defined by its public wealth - "the harbors, canals, roads, rivers, museums, prisons, hospitals, etc." (Dupuit, 1853, p. 17) - in addition to individual wealth as measured by the ratio of the quantity of wealth to the total population (Dupuit, 1865, p. 28). On the other hand, welfare increases if, and only if, individuals adopt good moral behavior. As welfare depends on the population level, Dupuit makes a value judgment concerning the good and bad behavior of individuals. Good behavior equals moral responsibility - restricting the number of children in the family in accordance with individual wealth and limiting the consumption of tobacco or alcohol (SEP, 1859 , p. 470). This moral responsibility derives from the capacity of individuals to act according to their own will. Indeed, if individuals are free to act, they are responsible for their acts and their consequences.

The relationship between these two causes of welfare (wealth and responsibility) is a cumulative process: the more responsible the individual is, the richer he will be and the

\footnotetext{
${ }^{15}$ In this article, the question of what Dupuit's expression "its members" refers to is not raised, since it does not fall within the framework of our problem relating to the clarification of the sources of ethical justice. Moreover, in this sentence Dupuit implicitly supposes that, other than natural liberty, natural rights cannot be in conflict with increasing welfare. The protection of certain natural rights is also part of the objective of society. See 3.2 .

${ }^{16}$ In this article, I will not explain why the objective of the social contract is the welfare of the country. This would involve summarising the emergence of such an objective and hence the notion of human nature in Dupuit's thought. However, that would extend beyond the framework of this article. In the same way, I will not explain whether or not the welfare of the nation is the summation of individual welfare.

${ }^{17}$ Dupuit only uses imprecise terms such as "aisance" (Dupuit, 1865, p. 6) or "jouissance" (1861b, p. 49) without defining them.

${ }^{18}$ On this point, Dupuit agrees with the French liberal school. This affirmation nevertheless supposes that the effects of the distribution of wealth between members of society on welfare are not considered. This problematic question will not be tackled here, as it diverges from the subject of this paper.
} 
richer he is, the more responsible he will be (Dupuit, 1865; SEP, 1862, pp. 472-5; SEP, 1863a, pp. 344-8). ${ }^{19}$

According to Dupuit, this process justifies measuring the level of welfare of a country by means of the average life expectancy: "in places where humans live for a long time, they are certainly more comfortable and their needs are better satisfied" (Dupuit, 1865, p. 6). "The average life expectancy", he adds, "may be considered as the true thermometer of the welfare of populations" (Ibid, p. 7).

An increase in the welfare of a country thus supposes either an improvement in the moral state of the population and/or an increase in wealth. In the case of the former, there is no need for the legislator to intervene directly. More precisely, Dupuit considers that the mission of the law is not to force individuals to adopt adequate moral behavior - only incentive mechanisms can be implemented to this end.

These mechanisms are either spontaneous - in which case they are the result of individual responsibility - or artificial. In the first case, for instance, behavior that is not in accordance with morality will result in the death of individuals who are incapable of satisfying their needs. In the second case, the law encourages individuals to modify their behavior, and this is how Dupuit justifies the system of taxes for private goods. ${ }^{20}$

Dupuit justifies state intervention in order to increase wealth and specifies the principles that must guide this intervention: the notion of "public utility" is therefore introduced into his analysis, referring here to an ethical conception of justice. ${ }^{21}$

\footnotetext{
${ }^{19}$ On this point, Dupuit uses the same argument as the French liberals (Sigot, 2010, p. 3).

${ }^{20}$ For private goods, taxes should be a function of the welfare of the nation. For example, in order to improve the health of a nation, taxes must incite individuals to consume 'good' instead of 'bad' products. Actually, at SEP, Dupuit claims that "taxes on sugar, coffee, and wine, have negative effects on the consumption of commodities which are useful to the welfare [and] the health of a population. In diminishing its consumption, the tobacco tax is more favourable than harmful to public health [and so to its welfare]" (1859, p. 470).

${ }^{21}$ The question of the principles guiding the legislator in his/her decisions is important, as it responds to the French liberals' attack on the notion of general interest. They state that the legislator must make his/her decisions in accordance with natural rights, in order to prevent arbitrary decisions from being taken in relation to the general interest (see Sigot, 2010, p. 12).
} 


\subsubsection{Utility conforms to moral justice}

Dupuit claims that the legislator is not free to decide the means of increasing wealth. This leads him to introduce another conception of justice into his analysis, not in its legal sense, but as a norm that enables public policies to be judged.

Since political economy is the science of wealth, the legislator must follow its recommendations with regard to public utility ${ }^{22}$ (Dupuit, 1844/1995, p. 128). This point has been examined in depth in secondary literature (see for example Ekelund \& Hébert, 1999; Etner, 1987; Mosca, 1998). However, in contrast to these commentators, I believe that welfare, general interest and public utility are different notions.

First, general interest is more global than welfare. Public interest is the conformity of public decisions with the objective of society to maximize welfare by restricting natural liberty as little as possible and protecting the other natural rights (see 3.2). Every law which increases welfare and protects all natural rights other than natural liberty therefore complies with the general interest.

Second, welfare differs from public utility. As we have seen, public utility is linked to wealth, itself linked to welfare; public utility is therefore a criterion for assessing whether or not the objective of increasing welfare is correctly pursued.

Besides being "the only solution to every problem of wealth appropriation", as I have already explained, the principle of public utility is the solution to "many other economic questions" (Dupuit, 1861b, p. 53). These questions include "the question of taxes, which is much better established and allocated if it does not harm the wealth [of the nation] [...] [or moreover], the question of the coalition or the association of certain interests which should only be authorized on the condition that it does not harm the public interest" (Ibid: footnote 1). Therefore, the means of making choices in order to increase wealth - public utility - must be distinguished from the objective of society - welfare.

\footnotetext{
${ }^{22}$ Dupuit defines public utility or the "Utilité absolue 'collective'" by the sum of the "utilité relative" of all consumers and the profits of the producer. An individual's utilite relative is represented by the difference between the maximum price that an individual is willing to pay for the service (what I call the 'individual' utilité absolue in order to differentiate it from 'collective' utilité absolue) and the asking price set by the producer (Dupuit, 1844/1995, 1849/1933, 1853). It should be noted that the concept of individual utilite absolue is different from the cardinality of utility. Indeed, Dupuit understands individual utilité absolue in the sense of an individual's preference for buying or not buying an object, rather than as a measure of his satisfaction (1844/1995, p. 65; see also Allais, 1989, p. 192 and Poinsot, 2007, p. 43). I do not use the term of present day micro-economics - "consumers' surplus" - because this could lead to confusion with respect to the concept developed by Alfred M arshall. The categories used by Dupuit are very different from M arshall's categories (see Béraud, 2005 and Poinsot, 2007).
} 
Public utility is, of course, correlated to welfare, although the former is only indirectly linked to the welfare of the population through the wealth of the country.

The most remarkable consequence of Dupuit's statement is that public utility conforms to what may be termed "ethical" or "moral" justice.

He claims that members of society have to respect laws because when "[positive] laws are established, it is unjust to disobey them" (Pascal quoted by Dupuit, 1861a, p. 333). The French liberals strongly oppose this statement, arguing that unjust laws exist. Dupuit recognizes this, but claims that unjust laws must also be respected by members of society, and laws which are not based on public utility are unjust (Dupuit, 1861b, pp. 49-50). Public utility thus becomes a norm for public decision-making. In my opinion, we can understand Dupuit as meaning that the welfare of the nation is the objective of society and every law that increases welfare conforms to ethical justice. As welfare increases with wealth and public utility is a criterion for increasing wealth, so public utility conforms to ethical justice. Hence, any laws that do not comply with public utility are unjust. This can be observed in Dupuit's criticism of the analysis of the French liberal school which, according to Dupuit, only defends private interests:

"In order to find out that [public] utility [conforms to ethical] justice, one only needs to adopt an alternative viewpoint to that of my honorable opponents, to depart from private interests and consider public interest. When one listens to certain commentators, it would appear that only the individual has rights and that society has one single right which is to defend them" (Ibid, p. 37).

Public utility is therefore a source of ethical justice. But are natural rights totally excluded from Dupuit's definition of ethical justice?

\subsection{Pure consequentialism? The persistence of natural rights}

At first glance, Dupuit seems to adopt a contradictory position. On the one hand, he claims that limiting natural rights in order to increase welfare conforms to moral justice:

"[Society] can only exist if some [positive] laws or conventions adjust the interaction of its members and the use of some objects, and restrict the liberty and the natural rights of individuals.

The general principle of these conventions is to provide the maximum possible overall welfare for all of the individual members of society, by respecting - insofar as this goal allows - their liberties and their natural rights, which are in themselves among the most precious forms of wealth" (Ibid, p. 53). 
On the other hand, he also states that the legislator has to respect natural rights. This is his position, for instance, on public expropriation. While he considers that property is not based on natural rights, he asserts that the legislator has to pay compensation in the event of expropriation. This is a direct consequence of Dupuit's conception of the respect of a contract as a natural right (item 4): "any owner of any form of property by virtue of a [precedent of positive] law, may only be deprived of said property on the condition that [s] he is granted an equivalent [indemnity]. This is a form of natural right" (Ibid, p. 48). In the same article, Dupuit claims that:

\begin{abstract}
"It is a great mistake to believe that a law may destroy what another law has established. If it has the character of a contract, and this is the case of property laws, it may only be changed with the consent of the contracting parties [...] The worker who earns 100,000 francs and buys either a plot of land, or a house [...] has an honorable property in his possession [...] It is equally true that it cannot be taken away from him without violating natural right [...] that it may only be taken away through provision of an indemnity." (Dupuit, 1861a, pp. 333-4). ${ }^{23}$
\end{abstract}

This argument concerning public expropriation raises an important issue: by basing his analysis on natural rights, without even referring to pains and pleasures, Dupuit clearly departs from Bentham's utilitarianism. ${ }^{24}$

But how can these two positions be compatible? Dupuit resolves this contradiction by stating that only natural liberty can be restricted: "we can demand no more liberty than what is suitable to public interest" (ibid, p. 51).

This relationship between natural rights (in particular natural liberty) and welfare in Dupuit's analysis is highly original in comparison to the French liberals' views. The latter believe that welfare is positively correlated to the defense of natural rights: the greater the protection of individuals' liberty and property, the more welfare increases (Garnier, 1875, p. 111; Molinari, 1861, p. VI). Natural rights therefore oppose neither welfare nor utility: the French liberals feel that an action that conforms to utility increases wealth, and

\footnotetext{
${ }^{23}$ On the question of international free trade, Dupuit makes the same claim. Indeed, in La liberté commerciale (1861c), Dupuit pronounces in favour of free trade as this will increase the quantity of wealth and hence the welfare of the nation. Free trade will nevertheless destroy certain economic interests. Dupuit therefore claims that a period of transition is necessary for considerations of justice. Indeed, "everything that prevents free trade condemns the population to work more to obtain less [...] decreasing the industrial power and also the political power of the country. Does this mean that after having existed for many years under a restrictive regime, a nation is supposed to achieve complete freedom without any form of transition? Probably not; this transition [...] [is necessary for] considerations of justice or equity with respect to certain interests [...]" (1861c, p. 2).

${ }^{24}$ As opposed to Dupuit, Bentham's argument lies in the pain caused in the absence of compensation. Indeed, this absence is perceived by individuals as reconsidering the positive right of property. A fear of this arises in society (which Bentham named an "alarm") implying a "pain of disappointed expectation".
} 
consequently welfare, and thus that the government must defend natural rights (Sigot, 2010, p. 1).

On the contrary, Dupuit claims that natural liberty should be limited in society by the legislator with a view to increasing welfare through wealth since it is not possible for the legislator to act directly on the other source of welfare, i.e. moral responsibility. More precisely, government is designed to maximize the welfare of the population, while preserving natural liberty as far as possible: "The best society is that in which the legislator gives each individual the maximum social advantages while imposing as few constraints on his/her natural liberty as possible" (1861b, p. 53). His position is interesting with respect to welfare comparisons: given two situations with the same level of welfare, the situation with greater respect for natural liberty should be preferred.

Dupuit's position nevertheless raises at least two problems.

First, Dupuit has to explain the absence of restrictions on natural rights other than natural liberty - self-ownership, self defense and the respect of contracts. His argument lies in the essence of the social contract, obliging the members of society to consent only to giving up their natural liberty: "to ask for an absolute, radical [and] complete liberty is to ask for the state of nature. [We must] accept the need for laws for the sake of public interest" (Ibid, p. 51).

Second, conflict may arise between the two aspects of the objective of society welfare and the protection of all natural rights other than natural liberty that the legislator cannot restrict. In this case, however, Dupuit does not specify how the legislator should make his decision and even implicitly supposes that it is impossible for him to do so.

In brief, Dupuit asserts that:

i. Ownership of things is not a natural right but a natural sentiment;

ii. Natural liberty can be restricted by the legislator with a view to maximizing welfare; and

iii. Three other natural rights remain that must be protected by the legislator: selfownership, self defense and the respect of contracts. This illustrates Dupuit's position with respect to ethical justice whereby ethical justice stems from both 
public utility and natural rights and this position applies to his dealing with the problem of financing public goods.

\subsection{The problem of financing public goods}

Dupuit distinguishes between private and public goods. The production of goods serves to increase the wealth of the country and the State is more efficient than a private company in producing and managing public goods: "If the State [alienates] the monopoly of a means of communication into the hands of a private company, this means immediately loses its economic characteristic as an inexpensive instrument of transport to become a machine for major profits" (Dupuit, 1854d, p. 853). Dupuit asserts that "we recognize that it falls within the government's functions, or departments of the government, to construct and to maintain certain means of communication" (Dupuit, 1854b, p. 380).

As far as public goods are concerned, two questions arise, the first concerning the financing principle to be adopted and the second concerning the rate of tax. In other words, the first question is "who has to pay for public goods?" while the second is "what rate of tax must they pay?" I will only examine the first question, since this is the area in which Dupuit's dual sources of ethical justice are the most clear-cut.

With regard to the principle of financing public goods, it seems that Dupuit distinguishes between public goods that are excludable (bridges, ships, canals, etc.) and those that are non-excludable (streets, courthouses, etc.). The former must be financed by their users while the latter must be financed by all members of society. In my opinion ${ }^{25}$, this distinction can be understood through the issue of restricting natural liberty. As we have already seen, for a given level of welfare, a state where natural liberty is less restricted is preferable to a more restrictive state.

Dupuit treats excludable public goods in the same way as private goods. It conforms to ethical justice in that only users pay for such services. ${ }^{26}$ Indeed, the user "is perfectly free

\footnotetext{
${ }^{25}$ This way of dealing with the question of financing public goods was suggested to me by one of the referees, whom I would sincerely like to thank.

${ }^{26}$ Dupuit only recommends taxing all members of society (users and non-users) for some excludable public services such as roads because "the State only charges directly for services that it provides when this can be achieved fairly and economically" (SEP, 1865, p. 132; see also 1854b, p. 556). He nevertheless adds that "theoretically, a traffic toll applied to roads would be fair and just" (SEP, 1865, p. 132).
} 
to buy it or not to buy it" (Dupuit, 1844/1995, p. 59). ${ }^{27}$ Hence, he states: "nobody can dispute the just character of the tax [that charges those who benefit from it], not even those who do not pay for it. In fact, it is obvious that if they did not find a certain advantage in using it, in spite of the toll, then they would not use it. Nothing justifies charging those who do not use this means of communication [...]" (Dupuit, 1854c, p. 556; see also SEP, 1865, p. 132).

In the case of non-excludable public goods, no contract is possible as nobody can be excluded from the service. In order to finance public goods, the legislator therefore has to diminish the natural liberty of the members of society by forcing them to contribute (even if they do not take advantage of such goods) and to make use of them: "No form of society is possible without a certain dose of communism; there are forms of wealth which must be personally appropriated, and there are the others that must remain collective, because of their intrinsic nature or destined usage" (Dupuit, 1863, p. 118). The government can force members of society to contribute either by means taxes or loans. Indeed, "there are [...] plenty of things that are of common and sustainable use, and for which the government, provincial or municipal councils can [...] legitimately borrow so that these things may be established. Public highways, streets, squares, markets, harbors, courts, prisons and so on require expenditure, whose burden may be transferred on to future generations without their having the right to complain"(SEP, 1860, p. 484).

Thus, according to Dupuit, all public goods from which some individuals can be excluded must be financed by their users, since this mode of taxation does not restrict natural liberty. However, when it is impossible to exclude individuals, the legislator may restrict natural liberty in order to finance this form of public good.

\footnotetext{
${ }^{27}$ This remark leads to the conclusion that non-users who benefit from excludable public goods should not pay for such goods. In actual fact, even if an individual profits from the existence of such goods, this benefit is independent of his or her will.
} 


\section{Conclusion}

In this article, I have attempted to demonstrate that a more general conception of ethical justice may be found in Dupuit's work than may be found in the secondary literature. Contrary to his commentators, Dupuit's originality does not stem from public utility; rather it results from the coexistence of two sources of ethical justice - welfare and natural rights. Through this conception of ethical justice, Dupuit differs from the French liberal school without for all that being bound by Bentham's utilitarianism. Indeed, even if his analysis leads to utilitarian conclusions, the absence of an a priori definition of rights that characterizes Bentham's utilitarianism contradicts Dupuit's position on natural rights.

Moreover, Dupuit's ethical justice is essential to an understanding of his economic analysis. In this paper, I have chosen to tackle the question of financing public goods, but many other subjects are concerned, such as Dupuit's justification of intellectual property rights or of the distribution of wealth. 


\section{References}

Allais, M. (1989). La théorie générale des surplus ( $2^{\text {nd }}$ ed.). Grenoble: Presses Universitaires de Grenoble.

Bastiat, F. (1847/2002), Discours au cercle de la librairie, 16 septembre 1847, Guillaumin reprint in D. Sagot-Duvauroux (2002), Les majorats littéraires : la propriété intellectuelle c'est le vol! (pp. 37-49). Dijon: Les Presses du Réel.

— (1848/1854-5). Propriété et loi. Journal des économistes, mai: 177-91; reprint in Fuvres complètes (pp. 275-297). Tome 4, Paris: Guillaumin et $C^{\mathrm{ie}}$.

Baudrillart, H. (1857). M anuel d'économie politique. Paris: Guillaumin.

— (1867). La propriété. Paris : L. Hachette.

Béraud, A. (2005). Richesse et Valeur: la contribution des économistes français du début du 19éme siècle. Economies et Sociétés, Cahiers de I'ISM EA, PE, OEconomia, 36, June, 100932.

Dupuit, J. (1844/1995). De la mesure de l'utilité des travaux publics. Annales des ponts et chaussées, s.II, t. VIII, 332-75 ; reproduced in Siroën, Jean-M arc (1995), Revue française d'économie, June, 55-93.

- (1849/1933). De l'influence des péages sur l'utilité des voies de communication. Annales des ponts et chaussées, s. II, t. XVII, 170-248; reproduced in Mario de Bernardi (1933), De I'utilité et de sa mesure (pp. 99-162). Torino: La riforma sociale, \& Paris: M arcel Giard.

— (1853). De l'utilité et de sa mesure. De l'utilité publique. Journal des Economistes, July, 127.

— (1854a). Péage. In C. Coquelin \& Guillaumin (eds), Dictionnaire de l'économie politique (pp. 339-44). Tome 2, Paris: Guillaumin. 
— (1854b). Ponts et Chaussées. In C. Coquelin \& Guillaumin (eds), Dictionnaire de l'économie politique (pp. 379-82). Tome 2, Paris: Guillaumin.

— (1854c). Routes et Chemins. In C. Coquelin \& Guillaumin (eds), Dictionnaire de l'économie politique (pp. 555-60). Tome 2, Paris: Guillaumin.

— (1854d). Voies de communication. In C. Coquelin \& Guillaumin (eds), Dictionnaire de l'économie politique (pp. 846-54). Tome 2, Paris: Guillaumin.

— (1861a). Du principe de propriété - Le juste et L'utile. Journal des économistes, January, 321-47.

— (1861b). Du principe de propriété - Le juste et L'utile - (suite et fin). Journal des économistes, April, 28-55.

— (1861c). La liberté commerciale - son principe et ses conséquences. Paris : Guillaumin.

— (1863). Compte rendu des 'Questions d'Économie Politique et de Droit Public' par M. G. De M olinari. Journal des économistes, January, 114-19.

- (1865). Des causes qui influent sur la longueur de la vie moyenne des populations. Journal des Economistes, July, 5-36.

Ekelund, R.-B., \& Hébert, R.-F. (1999). Secret Origins of M odern M icroeconomics. Dupuit and the Engineers. Chicago, IL: University of Chicago Press.

Etner, F. (1987). Histoire du calcul économique en France. Paris : Economica.

Faccarello, G. (2006). An 'Exception culturelle'? French Sensationist political economy and the shaping of public economics. The European Journal of the History of Economic Thought, 13(1), March, 1-38.

Faucher, L. (1852). Propriété. In C. Coquelin \& Guillaumin (1852), Dictionnaire de l'économie politique (pp. 460-73). Tome 2, Paris: Guillaumin.

Garnier, J. (1846). Éléments de l'économie politique; Exposé des notions fondamentales de 
cette science. Paris: Guillaumin.

— (1864). Premières notions d'économie politique ou sociale, ou industrielle (2nd ed.). Paris: Garnier Frères \& Guillaumin.

— (1873). Traité d'économie politique sociale ou industrielle: exposé didactique des principes et des applications de cette science et de l'organisation économique de la société (7th ed.). Paris: Garnier Frères.

— (1875). Premières notions d'économie politique ou sociale, ou industrielle (4th ed.). Paris: Garnier Frères \& Guillaumin.

Grall, B. (2004). Economie des forces et production d'utilité. La pensée gestionnaire des ingénieurs des ponts (1831-1891). Rennes: Presses Universitaire de Rennes.

Leter, M. (2006). Éléments pour une étude de l'école de Paris (1803-1852). In Philippe N. \& Jean P. (Eds.) (2006), Histoire du libéralisme en Europe (pp. 429-509). Paris: Presses Universitaire de France.

Molinari, Gustave de (1861). Questions d'économie politique et de droit public. Tome 1, Paris: Guillaumin.

Mosca, Manuela (1998). Jules Dupuit, the French 'ingénieurs économistes' and the Société d'Economie Politique. In G. Faccarello (ed.), Studies in the History of French Political Economy (pp. 254-83). London: Routledge.

Poinsot, Philippe (2007). De I'Intérêt Général à I'Utilité Collective, étude comparative des précurseurs de deux traditions: Jules Dupuit (1804-1866) et Alfred M arshall (1842-1924). Master Dissertation, University Paris 1 Panthéon-Sorbonne.

Sagot-Duvauroux, Dominique (2002a). Préface. Les majorats littéraires: la propriété intellectuelle c'est le vol ! (pp. 9-27). Dijon: Les Presses du Réel. 
- (2002b). Controverse sur le 'monautopole': Jules Dupuit face au droit d'auteur. In Simonin J. J. and Vatin F. (eds.) (pp. 117-126).

Sigot, Nathalie (2010). Utility and justice: French liberal economists in the $19^{\text {th }}$ Century. The European Journal of the History of Economic Thought.

Simonin Jean Pascal, \& Vatin François. (eds.) (2002), L'œuvre multiple de Jules Dupuit (18041866) - Calcul d'ingénieur, analyse économique et pensée sociale. Angers: Presses Universitaires d'Angers.

Société d'économie politique (1855). Des fondements du droit de propriété. Journal des économistes, January, 141-54.

— (1859). Justice de l'impôt du tabac. Journal des économistes, June, 469-74.

— (1860). Du paiement des dettes publiques et de l'amortissement ; -- des emprunts, dépense publique, et des fonctions de l'État. Journal des économistes, June, 480-507.

— (1862). De la justice au point de vue économique et relativement à la propriété. Journal des économistes, October, 146-54.

— (1863a). Question de la population. Journal des économistes, February, 330-58.

— (1863b). Sur la légitimité donnée aux propriétaires d'esclaves et de serfs. Journal des économistes, June, 462-76.

— (1865). De la suppression des droits de navigation sur les canaux et de l'amélioration des voies navigables. Journal des économistes, February, 131-38.

Smith, Cecil O. (1990). The Longest Run: Public Engineers and Planning in France. The American Historical Review, 95 (3), June, 657-692.

Vatin, François (2002). La morale utilitaire de Jules Dupuit. In Simonin J. J. and Vatin F. (eds) (pp. 91-116). 